\title{
Ayazmapınarı Tabiat Parkı'nın (Bayramiç, Çanakkale) Rekreasyonel Potansiyelinin Belirlenmesi Üzerine Bir Araştırma
}

\author{
Çiğdem Kaptan Ayhan
}

\begin{abstract}
Çanakkale Onsekiz Mart Üniversitesi Mimarlık ve Tasarım Fakültesi Peyzaj Mimarlığı Bölümü, 05056783541
Sorumlu yazar: cigdemayhan@yahoo.com
\end{abstract}

Geliş Tarihi: 24.05.2019

Kabul Tarihi: 25.06.2019

\section{Öz}

Rekreasyonel etkinlikler, sağlıklı bir yaşam sürdürebilmeleri açısından tüm insanlar için bir gerekliliktir. Açık ve yeşil alanlar rekreatif faaliyetler açısından son derece önemlidir. Ancak kent içinde, nüfusa paralel olarak artış göstermeyen veya doğal ve kültürel nitelikler açısından beklenen düzeyde olmayan bu alanlar, bireylerin kent yakın çevresindeki doğal - yarı doğal alanları tercih etme oranını artırmaktadır. Dolayısıyla, çeşitli özgün peyzaj özellikleri nedeniyle çeşitli kategorilerle koruma altına alınmış kent yakın çevresindeki orman alanları, rekreasyonel amaçlı kullanımlar açısından ayrıca önem kazanmaktadır. Korunan alanların rekreatif potansiyelini belirleme çalışmaları uzun yıllardır literatürde yer almaktadır. Bu çalışmalarda amaç; alanın rekreasyonel potansiyelinin nesnel ve bilimsel verilerle belirlenmesi ve mekânsal planlamalara bir temel oluşturmasıdır.

Bu çalışmada; Çanakkale ili Bayramiç İlçesine bağlı Ayazmapınarı Tabiat Parkı'nın rekreasyon potansiyelinin Gülez metodu çerçevesinde saptanması amaçlanmıştır. Elde edilen bulgular ve yapılan değerlendirmeler sonucunda alanın rekreasyon potansiyeli; \%69 sayısal değeriyle "yüksek" olarak belirlenmiştir. Ayrıca bu potansiyelin artırılabilmesi için planlama ve tasarım ölçeğinde çeşitli öneriler getirilmiştir.

Anahtar Kelimeler: Rekreasyon potansiyeli, Korunan alan, Tabiat Parkı, Gülez Metodu, Ayazmapınarı Tabiat Parkı, Çanakkale

\section{A Research on Determining the Recreational Potential of Ayazmapınarı Nature Park (Bayramiç, Çanakkale)}

\section{Abstract}

Recreational activities are a necessity for all people to be able to lead a healthy life. Open and green areas are extremely important for recreational activities. However, these areas do not increase in the city parallel to the population. In addition, they are not at the expected level in terms of natural and cultural qualities. This situation increases the preference of natural - semi - natural areas in the vicinity of the city. Therefore, forest areas in the vicinity of the city, which are protected by various categories due to various original landscape features, gain additional importance in terms of recreational uses. The studies on determining the potential of conservation of protected areas have been in the literature for many years. The purpose of these studies; is to determine the recreation potential of the area by objective and scientific data and to establish a basis for spatial planning.

In this study; it was aimed to determine the recreation potential of Ayazmapınarı Nature Park in Bayramiç District of Çanakkale within the framework of Gülez method. As a result of the findings and evaluations made, it was determined that the area has a high (\%69) recreation potential. In addition, various suggestions have been made to increase this potential.

Keywords : Recreational Potential, Protected Area, Nature Park, Gülez Method, Ayazmapınarı Nature Park, Çanakkale.

\section{Giriş}

Kentsel yaşamın monoton döngüsü içinde bireylerin yitirdikleri yaşam enerjilerini yeniden kazanmaları gerekmektedir. Günlük hayatın içinde çeşitli sorunlarla mücadele ederken fiziksel ve psikolojik açıdan yıpranan insanlar, toplum sağlığını da olumsuz etkilemektedirler. Cinsiyet, yaş, medeni durum, sosyo-ekonomik ya da sosyo-kültürel açılardan fark etmeksizin toplumun tamamı hayatlarının her aşamasında rekreasyona ihtiyaç duymaktadır.

Özkan (1981) rekreasyonu; sağlıklı yaşamak ve verimli çalışmak için insanın bozulan bütünlüğüne, dilediği aktivitelerle yeniden erişmesi olarak tanımlamaktadır. Kraus (1966)'a göre rekreasyon; kişi tarafından mutluluk duyacağı düşünülerel tercih edilen bir faaliyet ya da deneyimden 
oluşur. Boş zamanlarda ve işle bağlantısız olarak gerçekleştirilir (Veal, 1992). Parker (1979) ise rekreasyon kavramını; katılanların ruhsal ve fiziksel olarak kazanım sağladığı, rekabet etme gücü ve entelektüel bakış açısı elde ettiği etkinlikler temelinde tanımlamaktadır (Gül, 2014). Konuyla ilişkili başka birçok kaynakta çeşitli tanımlar yer almaktadır. Bu tanımların ortak noktası; rekreasyonun bireylere günlük rutin içinde kaybettikleri yaşam enerjisini yeniden kazanmaları yönünde destek olduğudur. Buradan hareketle; çalışma hayatındaki işgücü, verimlilik ve hatta iş sağlığı ve güvenliğine kadar farklı bir çok açıdan rekreasyon ve ilişkili kavramların son derece önemli olduğunu belirtmek yanlış olmayacaktır.

Rekreasyonel etkinlikler yapmak yukarıdaki tanımlardan da anlaşılacağı üzere tüm insanlar için bir gerekliliktir. Ancak bu etkinliklerin seçiminde Özkan (1981)'a göre birçok faktör (cinsiyet, fiziksel sağlık, yaş, sosyo-ekonomik ve sosyo-kültürel durum, meslek, yaşanılan yerin fiziksel niteliği vs) etkili olur. Ayrıca, etkinliklerin gerçekleştirildikleri alanlar da bireylerin rekreatif faaliyetlerden duyacakları memnuniyet seviyesini belirleyen en önemli faktörlerdendir. Bu alanlar öncelikle iç mekan ve dış mekan ikiye ayrılırken, dış mekan ya da açık hava olarak nitelendirilen rekreasyon alanları da kendi içlerinde kentsel ve kırsal rekreasyon alanları olarak sınıflandırılırlar.

Bugünün kentsel gelişim mekanizmasının odağında yerleşim ve ticaret alanları yer almaktadır. Yeşil alanlar ise bir konur pazarlama stratejisi olarak değerlendirilmektedir. Bu yoğun ve plansız gelişim süreci içinde kamunun kullanımına ayrılmış ve rekreasyonel faaliyetlere olanak sağlayan açık ve yeşil alanlar ise nitelik ve nicelik açısından yetersizdir. Ayrıca özellikle büyük kentlerde homojen dağılım göstermemektedir. Kentin nüfusuna paralel olarak artış göstermeyen veya doğal ve kültürel nitelikler açısından beklenen düzeyde olmayan bu alanlar, bireylerin kent yakın çevresindeki doğal - yarı doğal alanları tercih etme oranını artırmaktadır. Dolayısıyla, çeşitli özgün peyzaj özellikleri nedeniyle çeşitli kategorilerle koruma altına alınmış kent yakın çevresindeki orman alanları, rekreasyonel amaçlı kullanımlar açısından ayrıca önem kazanmaktadır.

Dünyada doğanın korunmasına yönelik organize ve küresel çalışmaların gerekliliğinin ortaya çıkmasıyla beraber 1948 yılında kurulan Uluslararası Doğa Koruma Birliği (International Union for Conservation of Nature- IUCN) doğal dünyanın statüsü ve onu korumak için gereken tedbirler konusunda küresel otorite haline gelmiştir. Bugün, aralarında devletler, sivil toplum örgütleri, yerel halk örgütlerinin de bulunduğu 1300 'den fazla üyesinin uzmanlığı ve 10.000 'den fazla uluslararası uzmanın desteğiyle dünyanın en yaygın ve en çeşitli çevresel ağı konumundadır. (Anonim 2019d).

Doğal dünyayı koruma ve yönetme açısından küresel öneme ve güce sahip olan IUCN, korunan alanı; ekosistem hizmetleri ve kültürel değerlerle ilgili olarak doğanın uzun vadede korunması amacıyla yasal olarak tanına, belirlenen ve yönetilen belirli coğrafi sınırları olan alanlar olarak tanımlarken, biyolojik çeşitliliğin korunmasında çok önemli rol oynadıklarını da ifade etmektedir. Ayrıca bu alanlar; işleyen doğal ekosistemleri sürdürmek, türler için özel alanlar sağlamak, yoğun şekilde kullanılan kara ve deniz peyzajlarındaki son derece hassas ekolojik süreçleri sürdürebilmek için ulusal ya da uluslararası neredeyse tüm koruma stratejilerinin temel taşlarıdır. Korunan alanların insanlara sağladığı direkt yararlar da mevcuttur. Sadece içinde ya da yakın çevresinde yaşayanlar değil daha uzaktakiler de, bu alanlardaki yaban türlerinin genetik potansiyeli ve doğal ekosistem hizmetleri (örneğin suyun varlığı ve kullanımı) sayesinde ortaya çıkan rekreasyon firsatlarından yararlanmaktadırlar. Buna ek olarak birçok korunan alan, hassas insan toplulukları ve kutsal kabul edilen doğal alanların korunması için son derece önemli ve gereklidir (Dudley, 2008).

Tüm dünyada çeşitli kategoriler altında korunan alanlar sınıflandırılmaktadır. Örneğin IUCN tarafından 1994 tarihinde önerilen altı adet koruma alanı statüsü (Mutlak Doğa Rezervleri, Yabanıl Alanlar, Milli Parklar, Doğal Anıtlar, Habitat/Tür Yönetim Alanları, Kara/Deniz Peyzajı Koruma Alanları ve Yönetilen Kaynak Koruma Alanları) (Dudley, 2008) aralarında Türkiye'nin de bulunduğu çeşitli ülkelerce kabul görmüş ve her ülke kendi yasal çerçevesi içinde bu kategorileri benimsemiş ve biçimlendirmiştir. Ancak bu tarihin öncesinde, Türkiye'deki özellikle orman rejiminde yer alan alanların korunması açısından, 1983 tarihinde Resmi Gazete'de ilan edilerek yürürlüğe giren 2873 sayılı Milli Parklar Kanunu ayrı bir öneme sahiptir. Kanunun amac1; Anonim (2019 b)'e göre; ulusal ve uluslararası düzeyde değerlere sahip milli park, tabiat parkı, tabiat anıtı ve tabiatı koruma alanlarının seçilmesi, belirlenmesi, içerdikleri özellik ve karakterlerin bozulmadan korunması, geliştirilmesi ve yönetilmesi açısından gerekli esasların belirlenmesidir. Bu çalışmanın da konusu olan Tabiat parkları Milli Parklar Kanunu'nda; "Bitki örtüsü ve yaban hayatı özelliğine sahip, manzara 
bütünlüğü içinde halkın dinlenme ve eğlenmesine uygun tabiat parçaları" olarak tanımlanmaktadır. Anonim, 2019 b). Türkiye'de, Tarım ve Orman Bakanlığı, Doğa Koruma ve Milli Parklar Genel Müdürlüğu 2018 verilerine göre 229 adet Tabiat Park1 mevcuttur (Anonim 2019 c). Bu kanun çerçevesinde tanımları yapılan koruma kategorilerinin haricinde, farklı bakanlık ve genel müdürlüklerin sorumluluğu altında yer alan çeşitli koruma statüleri de (özel çevre koruma bölgeleri, yaban hayatı geliştirme sahaları ve sit alanları) mevcuttur.

Yasadaki tanımında da yer aldığı gibi tabiat parkları, rekreasyon olanakları açısından ayrıca önemlidir. Ancak rekreatif kullanımların, alandaki doğal ekolojik süreçlere zarar vermeyecek şekilde planlanması ve yönetilmesi esastır. Alandaki ekosistemlerin varlığı ve korunması gerekliliği ile rekreasyonel amaçlar genellikle ters yönlerde ilerleyen iki farklı eylem durumundadır. Böylesi durumlarda alanın sahip olduğu rekreasyonel potansiyelin belirlenmesi ilerleyen süreçte kullanım çeşitliliği ve kullanım yoğunluğu açısından da yol gösterici olacaktır.

Rekreasyon potansiyelinin belirlenmesine yönelik olarak, ulusal ve uluslararası çeşitli çalışmalar bulunmaktadır (Gülez, 1992, Kliskey, 2000, Akten, 2003, Fleishman ve Feitelson, 2008, Paracchini ve ark., 2014, Birinci ve ark., 2016, Çetin ve Şevik, 2016, Dudek, 2017, Diktaş Bulut, 2018). Bunlar ve benzer çalışmalarda amaç; alanın rekreasyonel potansiyelinin mümkün olduğunca nesnel ve bilimsel verilerle belirlenmesi ve böyle mekânsal planlamalara bir temel oluşturmasıdır.

Bu çalışmada; Çanakkale İli, Bayramiç ilçesi sınırları içerisinde kalan Ayazmapınarı Tabiat Parkı'nın (ATP) rekreasyon potansiyeli Gülez metodu (Gülez, 1990) çerçevesinde saptanmıştır. Ayrıca alanın sürdürülebilir kullanımı açısından bugüne ve geleceğe yönelik mevcut ve olası sorunlar ve bunlara yönelik çözüm önerileri belirtilmiştir.

\section{Materyal ve Yöntem}

Çalışmanın ana materyalini ATP oluşturmaktadır. Buna ek olarak, araştırma konusuyla ilgili çeşitli yayınlar ve çalışma alanına ilişkin önceki çalışmalar, kurumlardan elde edilen bilgi ve belgeler, yerinde yapılan incelemeler sırasında alınan notlar ve çekilen fotoğraflar da araştırma materyali arasındadir.

Çalışma alanı, Çanakkale iline bağlı Bayramiç ilçesi, Evciler Köyü sınırları içerisindedir. Büyüklüğü 5,85 ha olup, 11.07.2011 tarihinde Tabiat Park1 olarak ilan edilmiştir (Şekil 1). Alan Çanakkale'ye $91 \mathrm{~km}$, Bayramiç'e $23 \mathrm{~km}$, Evciler Köyü’ne yaklaşık $6 \mathrm{~km}$ mesafede ve $490 \mathrm{~m}$

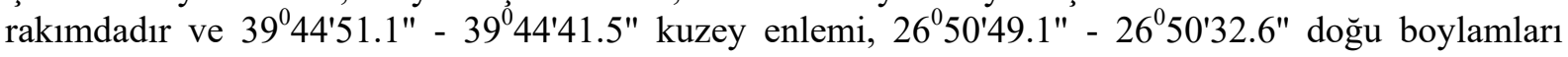
arasinda bulunur.

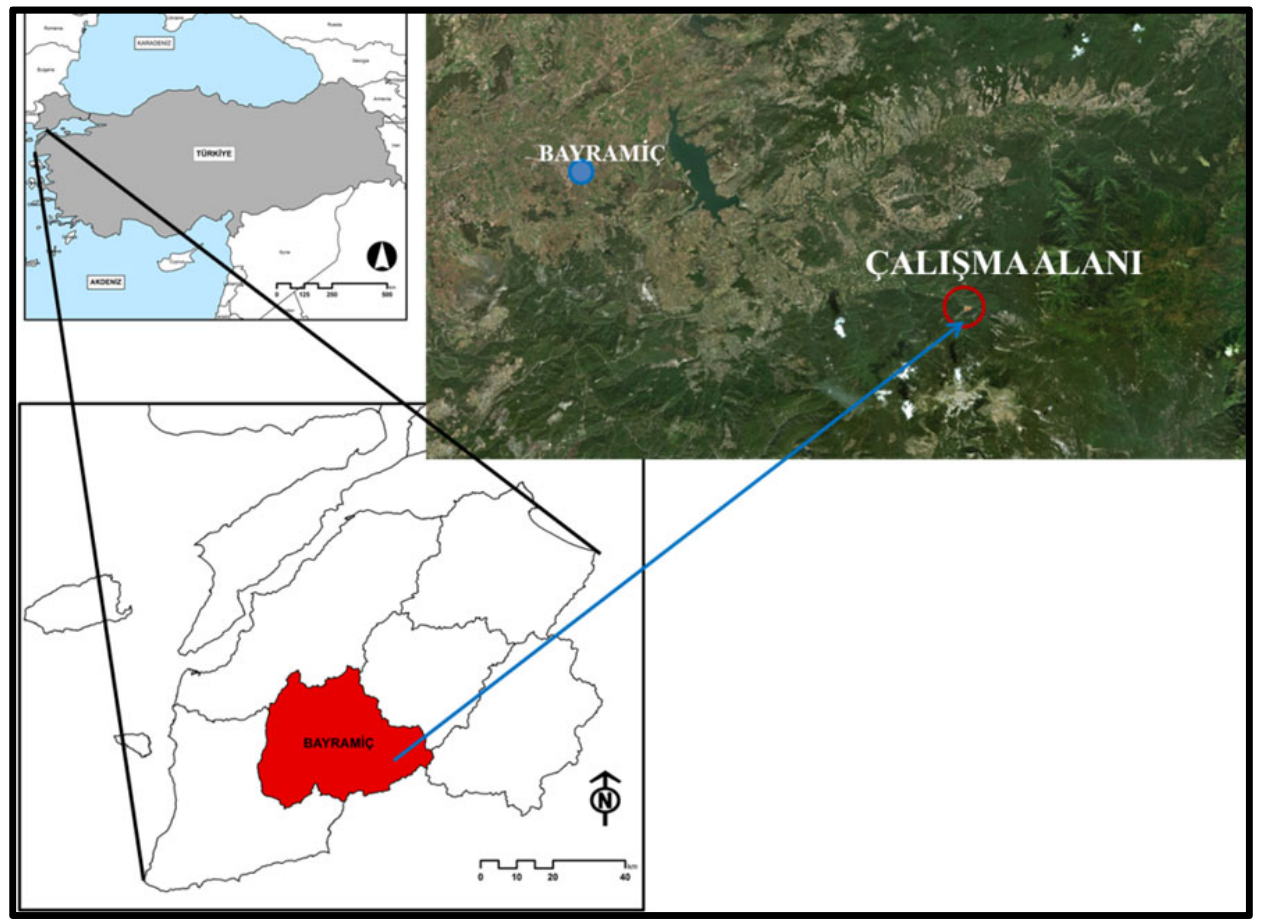

Şekil 1. Araştırma alanının coğrafi konumu 
Çanakkale ilinin tamamı Thornthwaite sınıflandırmasına göre "yarı kurak- az nemli" bir iklim özelliği göstermektedir (Şensoy ve ark., 2008). Erinç (1984)'e göre Türkiye'nin dört makro iktlim tipinden biri olan Akdeniz İklim Tipi’nin, Marmara alt iklim tipi içerisinde yer almaktadır. Buna göre, asıl Akdeniz iklimine göre daha az yaz sıcaklığı, oldukça soğuk kışlar, normal kar yağışı, daha sık don olayı ve daha fazla bulutluluk oranına sahiptir (Anonim 2019) ve "Yarı nemli" yağış etkinliği sınıfı içerisindedir (Bölük, 2016).

Bitki örtüsü açısından alan tamamen ormanla kaplıdır. ATP içinde hakim bitki örtüsünü Pinus nigra meşcereleri oluşturmaktadır. Ayrıca; Çınarcık ve Ayazma dereleri boyunca Karadeniz Bölgesi bitki örtüsü görülmektedir. Buralarda, (Castanea sp., Carpinus sp., Quercus sp., Tilia sp., Fagus sp., Pistacia sp., Phillyrea sp., Corylus sp., ve Pteridophyta sp.) gibi türler mevcuttur (Anonim, 2001).

Çalışma alanının faunasına yönelik bir çalışma bulunmamaktadır. Ancak bu konuda Kazdağları'na yönelik çalışmalar kısmen de olsa fikir vermektedir. Cürebal ve ark. (2012)'na göre; görsel bir zenginlik olarak böcekler ve kelebeklerin haricinde Kazdağları'nın omurgalı faunasının en yaygın üyeleri balıklar, amfibiler, sürüngenler, kuşlar ve memelilerden oluşur. Özellikle dağlık alan ekosisteminde soğuk sularda görülen büyük benekli alabalık (Salmo trutta macrostigma) dikkat çekici bir türdür. Ayrıca çeşitli kurbağa ve semender, yılan ve kertenkele türlerine de rastlanır. Kazdağları'nın kuş göç yolları üzerinde olması nedeniyle çeşitli kuş türleri de görülmektedir (Karatavuk (Turdus merula), tahtalı (Columba palumbus), yabankazı (Anser anser), kınalı keklik (Alectoris graeca), kuğu (Cygnus cygnus), kartal (Hieraetus pennatus)). Kazdağları'nda bozayı, kurt, çakal, yaban domuzu, karaca, tilki, kirpi, porsuk ve sincap gibi memeliler yaşamaktadır. Kızıl tilki (Vulpes vulpes) daha sık rastlanılan bir memelidir. Kazdağları ekosisteminde yaşayan en iri memeli hayvan bozayıdır (Ursus arctos). Bozayı bu ekosistemde doğal yayılış alanındadır. Sayıları 100 kadar olduğu sanılan boz ayı koruma altına alınmıştır. Kedigillerden vaşağın (Lynx lynx) varlığına dair bazı söylentiler olsa da şimdiye dek fotoğraflanamamıştır. Köpekgillerden kurta nadiren rastlanılmaktadır. Köpekgillerden olan sırtlana yörede andık adı verilir. Arada sırada bu hayvana ait haberler duyulmaktadır, fakat belgelenememiştir.

Alanda önemli su varlığı olarak; Çınarcık ve Ayazma derelerinden bahsetmek mümkündür. Alana ismini veren Ayazma Pınarı, alanın güneyinde yer almaktadır. Çınarcık deresi üzerinde yapılmış bir adet bentin hemen alt bölümündeki kayalıkların içerisinden 6 noktada su patlamaktadır. Çınarcık Deresi, bentten sonra dar ve dik kayalık vadi içerisinden geçerek, iç yolun üzerine yapılmış olan köprünün altından bir şelale halinde akarak cadı kazanı oluşumuna düşmekte ve bu noktadan sonra geniş bir kanyon içerisinden akarak saha dışına çıkmaktadır. Oldukça bol su kaynaklarına sahip olan alanın içme ve kullanma suyu problemi bulunmamaktadır (Anonim, 2001). ATP, zengin bitki örtüsüyle beraber dere ve şelalenin de varlığıyla görsel peyzaj açıdan oldukça ilgi çekicidir (Şekil 2). Ayrıca çalışma alanında, dere ve şelalenin kenarlarında konumlandırılmış piknik üniteleri ve orman içindeki yürüyüş rotalarıyla rekreasyonel açıdan tercih edilmektedir. Alanda, çocuk oyun alanı ve yerel ürünlere yönelik satış birimleri de bulunmaktadır. Orman ekosisteminin oluşturduğu mikroklima sayesinde çalışma alanı, özellikle sıcak yaz günlerinde yoğun olarak kullanılmaktadır.

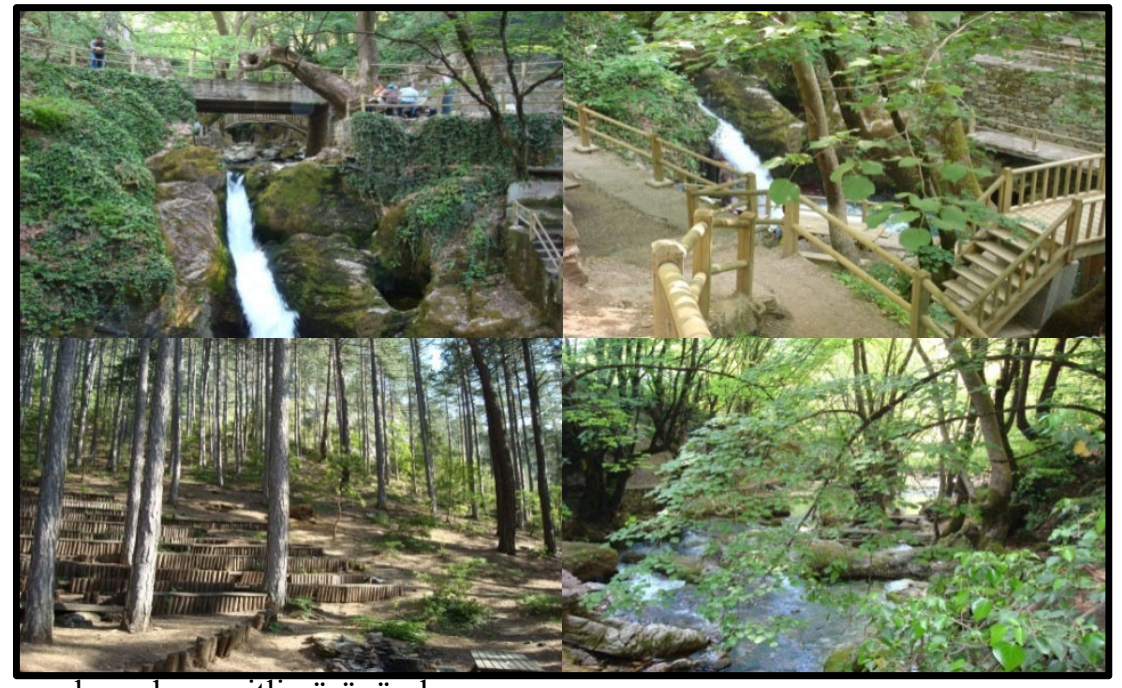

Şekil 2. Araştırma alanından çeşitli görünümler 
Alanın yer aldığ 1 Kaz Dağları ve Evciler Havzası, mitolojik açıdan son derece önemlidir ve Troya Bölgesinin merkezinde yer almaktadır. Yerleşme geçmişi olarak 6000 yıla varan bu yöre, tüm zenginliklerin kaynağı olarak kabul edilmektedir. Dünyadaki ilk güzellik yarışmasının Ayazma'da yapıldı ğından bahseden kaynaklar mevcuttur (Koç, 2008).

Çalışmada, Gülez (1990) tarafından ülkemiz koşulları için geliştirilen ve ormaniçi rekreasyona alanlarının açı hava rekreasyon potansiyelini ortaya koymayı amaçlayan yönteminden yararlanılmıştır. Yöntem; pratik bir formülasyonla alanın rekreasyon potansiyelini \% değer olarak saptamaya olanak tanımaktadır (Çizelge 1).

Çizelge 1. Formül öğeleri ve alabilecekleri puanlar (Gülez, 1990).

\begin{tabular}{lll}
\hline & & $\mathrm{P}+\dot{\mathrm{I}}+\mathrm{U}+\mathrm{RK}+$ OSE = \% RP \\
\hline Sembol & Açıklama & Maksimum Puan (Öğenin Ağırlık Puanı) \\
\hline $\mathrm{P}$ & Peyzaj Değeri & 35 \\
$\mathrm{I}$ & İklim Değeri & 25 \\
$\mathrm{U}$ & Ulaşılabilirlik & 20 \\
$\mathrm{RK}$ & Rekreatif Kolaylık & 20 \\
OSE & Olumsuz Etkenler & 0 (maksimum -10) \\
$\%$ RP & Rekreasyon Potansiyeli & 100 \\
\hline
\end{tabular}

Yukarıdaki formülasyon çerçevesinde doğru ve pratik bir değerlendirme yapılabilmesi amacıyla, öğelerin ve alabilecekleri maksimum puanların kendi içinde detaylandırıldığ 1 "Ormaniçi rekreasyon Potansiyeli Değerlendirme Formu" (ORPDF) oluşturulmuştur (Çizelge 2). Gülez Yöntemi'nin temeli bu forma dayanmaktadır.

Çizelge 2. Ormaniçi Rekreasyon Potansiyeli Değerlendirme Formu (Gülez, 1990)

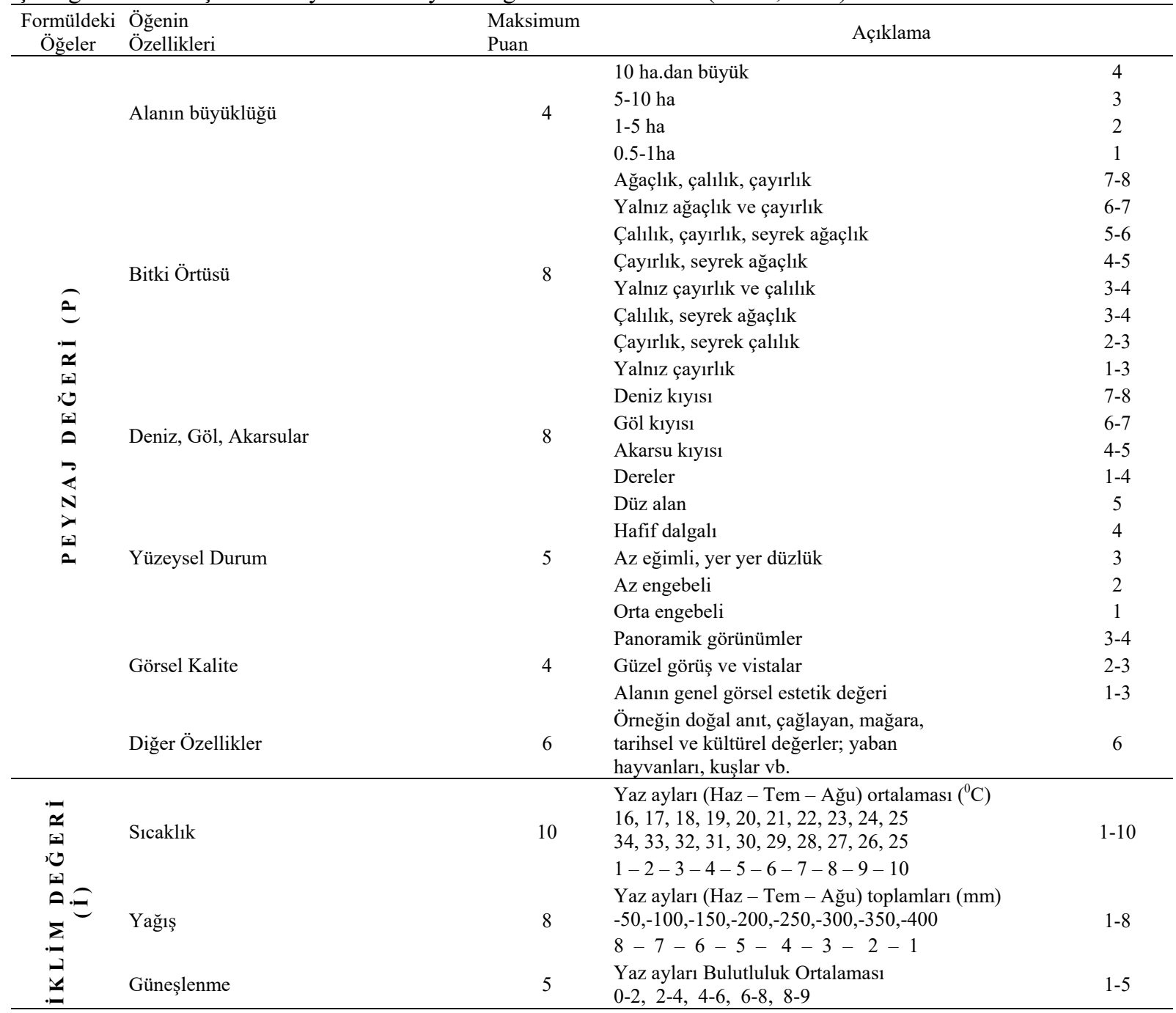




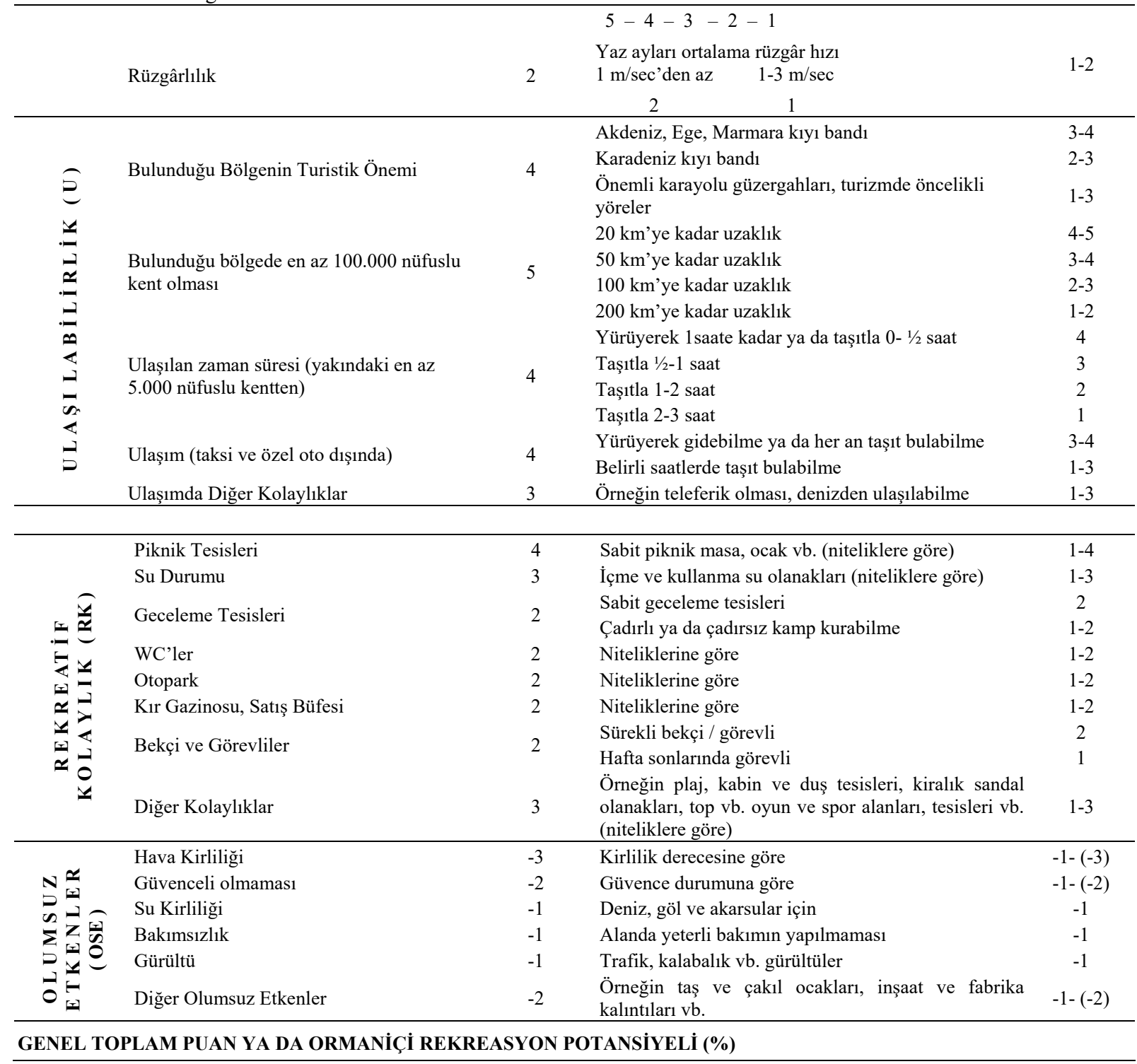

Gülez Yöntemi, iklim değerleri hariç diğer öğeleri araştırıcının değerlendirebilmesine ve karar verebilmesine olanak sağlaması açısından pratik ve hızlıdır. İklim değerleri; çalışma alanına en yakın meteoroloji istasyonundan temin edilerek değerlendirmeye katılır.

Çizelge 2'de yer alan değerlendirmeler sonucunda elde edilen puanlar alanın rekreasyon potansiyelinin belirlenmesini sağlayacaktır. Bu çerçevede Çizelge 3'te verilen skala yine Gülez (1990)'in yönteminde yer almaktadır.

Çizelge 3. Orman İçi Rekreasyon Potansiyeli ( OİRP) Değerlendirme Skalası

\begin{tabular}{ll}
\hline$\% 30$ 'dan aşağı & çok düşük \\
$\% 30-\% 45$ & düşük \\
$\% 46-\% 60$ & orta \\
$\% 61-\% 75$ & yüksek \\
$\% 75$ 'den yukarı & çok yükssek \\
\hline
\end{tabular}

\section{Bulgular ve Tartışma}

$\mathrm{Bu}$ çalışmada, ORPDF kullanılarak ATP değerlendirilmiş ve rekreasyon potansiyeli \%değer olarak belirlenmeye çalışılmıştır. Formda yer alan her bir öğe kurumlardan elde edilen veriler ve arazi gözlemleri sonucunda puanlandırılmıştır. Çalışma alanı ilk olarak Peyzaj Değeri (P) açısından 
irdelenmiştir. Alanın büyüklüğü, mevcut bitki örtüsü, herhangi bir su öğesinin varlığı, topografik yapı, görsel kalite ve diğer etmenler alanın rekreatif potansiyelini belirlemede önemli ölçüde yer almaktadır. Büyüklük açısından çalışma alanı; yüzölçümünün 5,85 ha olması nedeniyle yöntem çerçevesinde 3 puanla değerlendirilmiştir. Mevcut bitki örtüsü açısından oldukça zengin olması göz önüne alınarak, alan bu öğe açısından ATP 8 puan ile değerlendirilmiştir. Alanın içinden geçen Ayazma ve Çınarcık Dereleri nedeniyle "deniz, göl, akarsular" öğesi çerçevesinde 4 puan verilmiştir. Çalışma alanı, Anonim (2001)'e göre orta engebeli olarak belirtilmiş olmakla beraber çeşitli tesislerin kurulması ve inşası sırasında topografyada oluşan değişiklikler göz önüne alınarak az eğimli yer yer düzlük olarak değerlendirilmiştir (3 puan). Alan içinde özellikle dere ve şelalenin varlığ ve mevsim değişimlerinde yoğun bitki dokusuyla ortaya çıkan görünümler "Görsel Kalite" öğesi için önem taşımaktadır (3 puan). Şelalenin varlı̆̆ 1 ve mitolojik değerlerle alan "Diğer Özellikler" açısından 5 puanla değerlendirilmiştir. Yapılan puanlama sonucunda ATP'nın, "Peyzaj Değeri” puanı 27 olarak saptanmıştır.

İklim özellikleri rekreatif faaliyetler açısından en belirleyici faktörlerden birisidir. Yöntemde bu faktör, İklim Değeri ( İ ) olarak ele alınmıştır. Çalışmada; Tarım ve Orman Bakanlığı Meteoroloji Genel Müdürlüğü Bayramiç ve Çanakkale istasyonlarından temin edilen veriler kullanılmıştır. Sıcaklık, yağış ve rüzgar hızı verileri Bayramiç istasyonu ölçümlerinden, bulutluluk verisi ise Bayramiç’te ölçüm yapılmadığından Çanakkale istasyonundan elde edilmiştir. Çalışma alanın 20142018 yılları arası Haziran-Temmuz-Ağustos ayları ortalaması $24,6{ }^{\circ} \mathrm{C}$ 'dir ve yönteme göre bu öğenin puanı 9'dur. Yaz ayları toplam yăğş miktarı (2014-2018 yılları arası ortalaması) 95mm'dir ve bu nedenle 7 puanla değerlendirmeye alınmıştır. Alandaki bulutluluk ortalaması 2 olarak görülmektedir ve ORPDF'ndaki karşılığı 5 ya da 4 puandır. Çalışma alanın yoğun orman dokusuyla kaplı olması açısından bu puan 4 olarak uygun görülmüştür. Yine yaz aylarındaki ortalama rüzgar hızı 3,9 m/sn'dir ve 1 puanla değerlendirilmiştir. ATP'nın “İklim Değeri” açısından toplam puanı 21 'dir.

Ulaşılabilirlik (U) bir alanın rekreasyon potansiyelinin belirlenmesinde oldukça önemlidir. Rekreasyon alanının yerleşimlere olan mesafesi ve ulaşım araçlarında çeşitliliğin varlığ bireylerin tercihlerini ve alanın potansiyelini etkilemektedir. Çalışma alanı, son yıllarda turizm faaliyetleri açısından önemli bir ivme kazanmış olan Çanakkale ili sınırları içerisindedir. Ayrıca İzmir Çanakkale karayoluna da yakın konumdadır. Bu nedenle bölgenin turistik önemi açısından 3 puanla değerlendirilmiştir. ATP, nüfusu 100.000'den fazla olan Çanakkale'ye $91 \mathrm{~km}$, Edremit'e $107 \mathrm{~km}$ uzaklıktadır. Türkiye İstatistik Kurumu verilerine göre 2018 yılı nüfus sonuçları Çanakkale için 540.662, Edremit için ise 154.487'dir. Buna göre, bu öğe için alanın puanı 2 olarak belirlenmiştir. Nüfusu en az 5.000 olan bir yerleşimden (Bayramiç) çalışma alanına olan mesafe $23 \mathrm{~km}$ olup, ulaşım süresi ise taşıtla $1 / 2-1$ saattir dolayısıyla 4 puan verilmiştir. Bayramiç ilçe merkezinden Evciler köyüne her gün belirli saatlerde araç olmakla beraber Evciler köyünden çalışma alanına (yaklaşık $6 \mathrm{~km}$ ) ulaşım sadece taksi veya özel araçla mümkündür. Bu nedenle bu öğe çerçevesinde 1 puan verilmiştir. $\mathrm{Bu}$ değerlendirmelerle ATP'nin “Ulaşılabilirlik" puanı toplam 10'dur.

Bireylerin rekreasyonel faaliyetler için bir alanı tercih etmeleri o alandaki tesislerin varlığına ve niteliğine de bağlıdır. Alanın potansiyelini artıran ve çeşitlendiren bu faktör Gülez Yönteminde Rekreatif Kolaylık (RK) olarak nitelendirilmiştir. ATP içinde ziyaretçilerin kullanımına sunulmuş piknik masası ve barbekü olanakları mevcuttur. Ancak bunlar özellikle hafta sonu veya bayram tatillerinde yetersiz kalmaktadır. Bu nedenle bu öğe için 3 puan verilmiştir. İçme ve kullanma suyu olanakları yeterlidir ve 3 puanla değerlendirilmiştir. Sabit geceleme tesisi alan içinde olmayıp yakın bir konumda yer almaktadır. Bu yüzden, bu öğe yöntemde 2 puanla temsil ediliyor olmakla beraber ATP için 1 puan belirlenmiştir. Alanda çadırlı kamp kurabilme olanağı vardır ve 1 puanla değerlendirilmiştir. Ziyaretçilerin kullanımına sunulmuş olan WC ler için nitelikleri gereği 1 puan uygun görülmüştür. Otopark olanaklarının yetersizliği nedeniyle bu öğe için 1 puan belirlenmiştir. ATP içinde yerel ürünlerin satışa sunulduğu bir büfe mevcuttur (1 puan). Özellikle piknik amaçlı yakılan mangal ateşinin kontrolün sağlanması açısından alanda sürekli görevliler bulunmaktadır (2 puan). Mevcut çocuk oyun alanı "Diğer Kolaylıklar" olarak değerlendirilmiş ve bu öğe için de 1 puan belirlenmiştir. Bu puanlamalar sonucunda 14 puan elde edilmiştir.

ORPDF'nda, alanın değerlendirilmesine yönelik olumlu özelliklerin yanı sıra olumsuz etkenlere (OSE) de yer verilmiştir. Bu açıdan irdelendiğinde; ATP'nda, özellikle yoğun ziyaretin gerçekleştiği tatil günlerinde bakım sorunlarıyla karşılaşılmaktadır. Ayrıca yine yoğun sezonda ziyaretçi sayısının fazla olması özellikle araç trafiği açısından sorun oluşturmaktadır. Bu nedenlerle 
her iki öğe için de -1 puan uygun görülmüştür. Alanda özellikle tatil günlerinde piknik üniteleri yetersiz kalmaktadır. Yazılı ve sözlü uyarılara rağmen ziyaretçiler bireysel mangal vs kullanarak piknik ateşine izin verilmeyen alanları da kullanmaktadırlar. Bu durum, yangın riski oluşturması açısından büyük tehlike yaratmaktadır. Ayrıca orman içi yolunu yürüyüş vb. faaliyetler için kullanmak isteyen bireyler özellikle mangal kaynaklı kokudan rahatsız olmaktadırlar. Ek olarak piknik alanı olarak ayrılmamış bu alanların kullanımı özellikle çöp açısından büyük sorun oluşturmaktadır. Bu nedenle "Diğer Olumsuz Etkenler" öğesi için -1 puan uygun görülmüş ve toplamda alan, OSE açısından -3 olumsuz puan almıştır.

$\mathrm{Bu}$ saptamalar 1şı̆̆ında; ATP'nın rekreasyon potansiyeli, Çizelge 1'de yer alan formül çerçevesinde; $27(\mathrm{P})+21(\mathrm{I})+10(\mathrm{U})+14(\mathrm{RK})+(-3)(\mathrm{OSE})=69$ olarak saptanmıştır. Bu toplam puan göz önüne alındığında, Çizelge 3 'te yer alan değerlendirme skalasına göre ise çalışma alanının Rekreasyon potansiyelinin "yüksek" olduğu belirlenmiştir.

\section{Sonuç ve Öneriler}

Rekreasyon potansiyelinin belirleme çalışmaları farklı ölçeklerde çok uzun zamandır literatürde mevcuttur. Özellikle orman içi alanların bu açıdan değerlendirilmesi açısından Gülez Yöntemi oldukça pratik ve sade bir yolla sonuca ulaşmayı sağlamaktadır. Bu çalışmada; Bayramiç ilçesine bağlı Evciler Köyü'ne 6km uzaklıkta bulunan Ayazmapınarı Tabiat Parkı'nın açıkhava rekreasyon potansiyelinin belirlenmesi amacıyla gerçekleştirilmiştir. Elde edilen sonuçlara göre alan, “yüksek" rekreasyon potansiyele sahiptir.

$\mathrm{Bu}$ potansiyelin artırılması, yukarıda söz edilen ve OSE olarak değerlendirilen niteliklerin iyileştirilmesiyle mümkün olabilecektir. ATP'na en azından yaz aylarında düzenli araç seferleri yapılmaya başlanması bu açıdan önem taşımaktadır. Piknik ünitelerinin sayıca artırılması ve niteliklerinin iyileştirilmesi ve gerekli bakım onarımlarının yapılması kullanıcı memnuniyetini artıracaktır. Hijyen ünitelerinin niteliği iyileştirilmeli ve yaz sezonunda alandaki ziyaretçi artışına hizmet verebilir hale getirilmelidir. Satış büfelerinde hizmet kalitesi açısından kontrol mekanizması çalıştırılmalıdır. Otopark olanakları, alan içi yolların dar oluşu ve topografik yapıdan kaynaklı kısıtll1ıklar nedeniyle oldukça yetersizdir, belirli bir otopark düzenlemesi olmayıp araçlar yol kenarlarına park edilmektedir. Bu durum hem yayalar hem de manevra yapmak isteyen sürücüler açısından sorun oluşturmaktadır. Alanın kendine özgü koşulları dikkate alınarak işlevsel otopark alanları tasarlanmalıdır. Çocuk oyun alanında yer alan üniteler geliştirilmeli, bakım ve onarım çalışmaları aksatılmamalıdır. Alan içinde sirkülasyonun bir bölümü ahşap köprü ve merdivenlerle sağlanmaktadır. Özellikle dere kenarına inilen ve kot farkının 4-5 m'ye ulaştığı noktalarda yer alan merdivenlerin ergonomik açıdan uygun hale getirilmesi gerekmektedir. Alanda mangal yakılmasına sadece belli noktalarda izin verilmektedir. Ancak ziyaretçi yoğunluğu nedeniyle orman içi yol kenarlarında bulunan piknik ünitelerinde de mangal yakıldığı ve görevlilerin uyarılarının bir yaptırım oluşturmadığı gözlenmiştir. Bu konuda alan içi görevli sayısının artırılması, cezai işlem uygulanması vb çözümlerle alanda oluşan bu yangın tehlikesinin engellenmesi gerekmektedir. Bunlara ek olarak; başta yöre halkı olmak üzere alanı ziyarete gelen tüm bireyleri alanın doğal ve kültürel peyzaj özellikleri açısından bilinçlendirmek son derece önemlidir. Dikkat çekici, basit ve anlaşılır bir dille yazılmış ve yetişkinler ve çocuklar için ayrı ayrı hazırlanmış bilgilendirme panoları, koruma kullanma dengesine hizmet edecektir. Bu önlemlerin alınmasıyla alanın toplam puanı 10 puan kadar artacak ve alanı; açıkhava rekreasyon potansiyeli açısından "çok yüksek" olarak değerlendirmek mümkün olabilecektir.

Yukarıda sözü edilen tüm değerlendirmeler ATP'nın rekreasyonel potansiyelini belirleme ve artırma yönündedir. $\mathrm{Bu}$ potansiyelle beraber oluşan turizm hareketleri, kırsal kalkınma açısından önemlilik arz etmektedir. Ancak bu noktada alanın sahip olduğu doğal peyzaj özelliklerinin korunması olayın bir diğer boyutudur. Kuss ve Graefe (1985)'nin de belirttiği gibi rekreasyonel açıdan önemli potansiyel içeren alanlarda karşılaşılan en büyük sorun; karar vericilerin ve alan yöneticilerinin doğal peyzajı korumaya yönelik çalışmalarıyla turizm ve rekreasyon amaçlı kullanımların çakışması aynı paralelde ilerleyememesidir. Ayhan ve ark. (2018), alanın taşıma kapasitesini belirlemeye yönelik yaptıkları çalışmada alanın 1 yıl içinde kabul edebileceği ziyaretçi sayısını 30.660 olarak belirlemiş, bununla beraber 2014 yılı verilerine göre alanın toplam ziyaretçi sayısının 55.764 olduğunu ifade etmişlerdir. Bu durumun doğal peyzaj açısından önemli bir sorun oluşturduğunu söylemek yanlış 

Dağı ve kuzeyindeki Evciler Havzası olduğunu belirtmektedir. ATP'nın da içinde yer aldığı bu çevreyi ilgilendiren tüm planlamalarda bu durum özellikle dikkate alınmalıdır.

Sonuç olarak; özellikle orman içi korunan alanlar rekreasyon faaliyetleri için yoğun olarak tercih edilmektedir. Elbette ki bu alanların rekreatif işlevleri de vardır ancak turizm ve rekreasyona yönelik planlamalar yapılırken, koruma-kullanma dengesi gözetilmesi birincil şart olmalıdır. Kent içi ve yakın çevrelerindeki yeşil alanlar, bireylerin taleplerini karşılamada yetersiz kalmaktadır. Orman içi doğal alanlara yönelik kullanım yoğunluğunun azaltılması amacıyla kent içi açık ve yeşil alanlarının artırılması, niteliklerinin iyileştirilmesi, kent ormanları oluşturulması vb. gibi planlama ve tasarım çalışmaları sürdürülebilirlik yolunda atılması gereken adımlar arasındadır.

\section{Kaynaklar}

Akten, M., 2003. Isparta İlindeki Bazı Rekreasyon Alanlarının Mevcut Potansiyellerinin Belirlenmesi. Süleyman Demirel Üniversitesi Orman Fakültesi Dergisi. 2:115-132.

Anonim, 2001. Ayazma Orman İçi Dinlenme Plan Raporu. Orman Bakanlığı Milli Parklar ve Av-Yaban Hayatı Genel Müdürlüğü, Ankara.

Anonim 2019a. Resmi Gazete, http://www.resmigazete.gov.tr/arsiv/18132.pdf, Erişim tarihi 18.02.2019

Anonim 2019b. Doğa Koruma ve Milli Parklar Genel Müdürlüğü WEB Sayfası http://www.milliparklar.gov.tr/korunan-alanlar/tabiat-parklari , Erişim tarihi 18.02.2019.

Anonim 2019c. Doğa Koruma ve Milli Parklar Genel Müdürlüğü WEB Sayfas1, http://ayazmapinari.tabiat.gov.tr/, Erişim tarihi 18.02.2019

Anonim, 2019d. Uluslararası Doğa Koruma Birliği WEB Sayfası, https://www.iucn.org/about/iucn-brief-history, Erişim tarihi 02.03.2019

Birinci, S., Zaman, M., Bulut, İ., 2016. Limni Gölü Tabiat Parkının (Gümüşhane) Rekreasyon Potansiyeli. Uluslararası Sosyal Araştırmalar Dergisi. 9(46): 285-294.

Bölük, E., 2016. Erinç İklim Sınıflandırmasına Göre Türkiye İklimi. Meteoroloji Genel Müdürlüğü WEB sayfası, https://www.mgm.gov.tr/FILES/iklim/iklim_siniflandirmalari/erinc.pdf, erişim tarihi 12.04.2019.

Cürebal, İ., Efe R., Sönmez, S., Soykan, A., 2012. Kazdağları Ekosistemi ve Ekolojisi. Kazdağları Ulusal Çalıştayı. Bildiriler Kitabı, 2-3 Haziran 2012, Güre-Edremit-Balıkesir.

Çetin, M., Şevik, H., 2016. Evaluating the Recreation Potential of Ilgaz Mountain National Park in Turkey. Environmental Monitoring Assessment. 188(52) https://doi.org/10.1007/s10661-015-5064-7 .

Diktaş Bulut, N., 2018. An approach to determining forest areas with recreational potential: The case of forest areas around main transportation roads in the Maçka Region of Trabzon, Turkey, Journal of Sustainable Forestry. 37:3, 286-301, DOI: 10.1080/10549811.2017.1406374

Dudek, T., 2017. Recreational Potential as an Indicator of Accessibility Control in Protected Mountain Forest Areas. Journal of Mountain Science. 14(7) : 1419-1427. DOI: 10.1007/s11629-016-4018-z.

Dudley, N., (Editor) 2008. Guidelines for Applying Protected Area Management Categories. Gland, Switzerland: IUCN. $x+86$ pp.

Fleishman, L., Feitelson, E., 2009. An Application of the Recreation Level of Service Approach to Forests in Israel. Landscape and Urban Planning. 89(3-4): 86-97.

Gül, T., 2014. Rekreasyon Olgusuna Genel Yaklaşım. Rekreasyona Giriş, Ed. Yaylı, A., Detay Yayıncılık, 202 s. Ankara.

Gülez, S., 1990. Orman İçi Rekreasyon Potansiyelinin Saptanması İçin Geliştirilen Bir Değerlendirme Yöntemi. İstanbul Üniversitesi Orman Fakültesi Dergisi. 40:2, 132-140.

Kaptan Ayhan, Ç., Karakaya, N., Kırıt, N., Özdemir, E., Yanmaz, K., 2018. The Concept of Carrying Capacity in Terms of Sustainable Use Policies: A Case Study of Bayramiç Ayazmapınarı Natural Park (Çanakkale, Turkey). Journal of Scientific Perspectives. 3: 135-150.

Kliskey, A.D., 2000. Recreation Terrain Suitability Mapping: A Spatially Explicit Methodology for Determining Recreation Potential for Resource Use Assessment. Landscape and Urban Planning. 52(1): 33-43.

Koç, T., 2008. Bayramiç Barajı Havzası (Evciler, Çanakkale) Potansiyeli ve Olası Sorunları. Bayramiç Değerleri Sempozyumu. Bildiriler Kitabı : 1-28. 29 Ağustos 2008, Bayramiç- Çanakkale.

Kuss Fred, R., Graefe Alan, R., 1985. Effects of Recreation Trampling on Natural Area Vegetation. Journal of Leisure Research. 17(3): 165-183.

Özkan, B., 2001. Kentsel Rekreasyon Alan Planlaması. Ege Üniversitesi Ziraat Fakültesi Peyzaj Mimarlı̆ı Bölümü, 79 s. İzmir.

Paracchini, M.L., Zulian, G., Kopperoinen, L., Maes, J., Schägner, J.P., Termansen, M., Zandersen, M., PerezSoba, M., Scholefield, P.A., Bidoglio, G., 2014. Mapping Cultural Ecosystem Services: A Framework to Assess the Potential for Outdoor Recreation Across the EU. Ecological Indicators, 45: 371-385. 
ÇOMÜ Zir. Fak. Derg. (COMU J. Agric. Fac.)

2019: 7 (1): 219-228

ISSN: $2147-8384$ / e-ISSN: 2564-6826

doi: 10.33202/comuagri.569906

Sensoy, S., Demircan, M., Ulupınar, Y., Balta, İ., 2008. Türkiye İklimi. Devlet Meteoroloji İşleri Genel Müdürlüğü, https://www.mgm.gov.tr/FILES/genel/makale/13_turkiye_iklimi.pdf, Erişim tarihi 15.02.2019.

Veal, A.J., 1992. Definitions of leisure and recreation. Australian Journal of Leisure and Recreation. 2(4): 4448, 52, http://funlibre.org/biblioteca2/docs_digitales/investigacion/definiciones_ocio_y_recreacion.pdf , Erişim tarihi 01.04.2019. 
